\begin{tabular}{|l|l|r|}
\hline & Al Fitrah & Memahami Perkembangan Psikologi \\
Journal Of Early Childhood Islamic Education & Keagamaan Anak Usia Dini \\
ISSN : 2599-2287 E-ISSN : 2622-335X & Fatrica Syafri \\
\hline & Vol.2 No.1 Juli 2018 & \\
\hline
\end{tabular}

\title{
MEMAHAMI PERKEMBANGAN PSIKOLOGI KEAGAMAAN ANAK USIA DINI
}

\begin{abstract}
Abstrak
Kajian ini mendeskripsikan tentang perkembangan psikologi keagamaan anak usia dini. Hal ini penting karena anak usia dini adalah usia emas yang harus dikembangkan potensi keagamaannya secara optimal. Potensi jiwa keagamaan anak telah ada sejak dalam kandungan, setelah dilahirkan membutuhkan stimulus lingkungan keluarga, sekolah dan masyarakat dalam mengembangkannya. Pada anak usia dini perkembanganya baru bersifat the fairy tale stage (tingkat dongeng), the raelistic stage (tingkat kenyataan), dan The Individual Stage (tingkat individu). Semua fase memiliki ciri khusus yang harus diperhatikan para guru dan orang tua, serta masyarakat sebagai pemberi stimulus terhadap perkembangan psikologi keagamaan anak usia dini.
\end{abstract}

Kata Kunci : Perkembangan, Psikologi, Keagamaan, dan Anak Usia Dini.

Fatrica Syafri

fatricasyafri@iainbengkulu.ac.id

IAIN Bengkulu

\section{Pendahuluan}

baru akan berfungsi jika kematangan dan

Anak dilahirkan dengan sistem pemeliharaan serta bimbingan dapat diarahkan penciptaan terbaik oleh Allah swt, ia telah memiliki kemampuan bawaan yang bersifat laten. Potensi bawaan ini memerlukan pengembangan melalui bimbingan dan pemeliharaan yang mantap lebih-lebih pada anak usia dini. Perkembangan jiwa keagamaan pada anak hampir sepenuhnya autoritas, maksudnya konsep keagamaan itu akan bekembang pada diri mereka dipengaruhi oleh faktor dari luar diri mereka. ${ }^{1}$

Fisik atau jasmani manusia baru akan berfungsi secara sempurna jika dipelihara dan dilatih. Akal dan fungsi mental lainnya pun

1 Jalaluddin, Psikologi Agama, (Jakarta: Raja Grafindo Persada, 2005), hlm. 70

2 Zakiah Darajat, Ilmu Jiwa Agama, (Jakarta: Bulan Bintang, 1987), hlm. 50. 


\begin{tabular}{|l|l|r|}
\hline A1 Fitrah & Memahami Perkembangan Psikologi \\
\hline Journal Of Early Childhood Islamic Education & Keagamaan Anak Usia Dini \\
ISSN : 2599-2287 E-ISSN : 2622-335X & Fatrica Syafri \\
\hline
\end{tabular}

dengan lingkungan anak berada. Sesuai dengan prinsip pertumbuhannya, seorang anak yang tumbuh dewasa, menurut Jalaluddin, memerlukan bimbingan sesuai dengan prinsip yang dimilikinya, yaitu prinsip biologis, prinsip tanpa daya, dan prinsip eksplorasi. ${ }^{3}$

Orang tua yang memiliki tanggung jawab terhadap pembinaan, bimbingan, pengembangan serta pengarahan potensi yang dimiliki anak agar mereka dapat berfungsi dan berperan sebagaimana hakikat kejadiannya, tentu sangat perlu memahami secara serius perkembangan jiwa agama anak usia dini, sebagaimana yang dikemukakan oleh Jalaluddin bahwa pengaruh bimbingan Ibu Bapak memiliki peran strategis dalam membentuk jiwa agama pada diri anak. ${ }^{4}$

$$
\text { Demikian pentingnya pengaruh }
$$

bimbingan itu, hingga dikaitkan dengan aqidah, sebab bila dibiarkan berkembang dengan sendirinya, maka potensi keberagamaan pada anak akan salah arah dan sulit untuk mengembangkannya secara optimal. Berdasarkan pemikiran-pemikiran di atas, terutama tentang pentingnya memahami perkembangan jiwa agama anak usia dini, maka penulis merasa perlu untuk mengkaji lebih seksama tentang proses perkembangan jiwa agama anak usia dini.

Pertumbuhan Agama pada Masa AnakAnak

Dasar nilai-nilai agama ditanamkan pada anak-anak pada masa sekolah dengan tahapan

3 Jalaludin, Psikologi Agama, (Jakarta: Rajawali Press, 2004), hal. 64.

${ }^{4}$ Jalaludin, Psikologi Agama, hal. 62. sesuai dengan usia dan untuk menerima kenyataan akan hal-hal yang tidak selamanya rasional. Ajaran agama dengan pola fisik maupun psikis anak-anak di usia sekolah dasar menunjukkan peran penting psikologi yang menjadikannya berkaitan erat dengan agama. Hal ini berkaitan dengan perkembangan intelektualitasnya yang semakin berkembang.

Menurut Zakiah masa pertumbuhan pertama (masa anak-anak) terjadi pada usia 012 tahun. Bahkan, lebih dari itu menurutnya sejak masa kandungan pun, kondisi dan sikap orang tua telah mempunyai pengaruh terhadap pertumbuhan jiwa keagamaan anaknya, meskipun sebagian ahli berpendapat bahwa ketika anak dilahirkan,ia bukanlah mahkluk yang religius. ${ }^{5}$

Sesuai dengan prinsip pertumbuhannya, seorang anak yang tumbuh dewasa, menurut Jalaluddin, memerlukan bimbingan sesuai dengan prinsip yang dimilikinya, yaitu berikut. ${ }^{6}$

1. Prinsip biologis. Secara fisik,anak yang baru dilahirkan berada dalam keadaan lemah. Dalam segala gerak dan tindak-tanduknya, ia selalu memerlukan bantuan dari orangorang dewasa sekelilingnya. Dengan kata lain, ia belum dapat berdiri sendiri karena manusia bukanlah mahkluk instinktif. Keadaan tubuhnya belum tumbuh secara sempurna untuk difungsikan secara maksimal.

5 Bambang Samsul Arifin, psikologi agama, (CV.PustakaSetia: Bandung, 2008). hlm, 47

6 Jalaludin, Psikologi Agama, (Jakarta: Rajawali Press, 2004), hal. 64 


\begin{tabular}{|l|l|r|}
\hline & Al Fitrah & Memahami Perkembangan Psikologi \\
Journal Of Early Childhood Islamic Education & Keagamaan Anak Usia Dini \\
ISSN : 2599-2287 E-ISSN : 2622-335X & Fatrica Syafri \\
\hline & Vol.2 No.1 Juli 2018 & \\
\hline
\end{tabular}

2. Prinsip tanpa daya. Sejalan dengan belum sempurnanya pertumbuhan fisik dan psikisnya, anak yang baru dilahirkan hingga menginjak usia dewasa selalu mengharapkan bantuan dari orang tuanya.

3. Prinsip eksplorasi. Kematapan dan kesempurnaan perkembangan potensi manusia yang dibawa sejak lahir, baik jasmani maupun rohani, memerlukan pengembangan melalui pemeliharaan dan latihan. Jasmaninya baru akan berfungsi secara sempurna jika dipelihara dan dilatihan.

\section{Timbulnya Agama pada Anak}

Dalam melihat timbunya agama pada anak usia dini terdapat dualisme pendapat mengenai keberadaan kejiwaan anak yang baru dilahirkan, apakah sebagai mahluk religius atau bukan. Namun demikian, fakta dan berdasarkan teks-teks dan pengalaman keagamaan yang dilalui manusia menunjukkan bahwa anak yang baru dilahirkan pun telah membawa fitrah keagamaan, meskipun fungsinya baru tampak setelah berada pada tahap kematangan di kemudian hari melalui proses bimbingan dan latihan. Perkembangan jiwa beragama pada masa anak-anak sejak dilahirkan telah membawa fitrah keagamaan dan baru berfungsi kemudian setelah melalui bimbingan dan latihan sesuai dengan tahap perkembangan jiwanya.

Menurut Thomas bahwa manusia di lahirkan kedunia ini memiliki empat keinginan yaitu: keinginan untuk selamat, keinginan untuk mendapatkan pengalaman baru, keinginan untuk mendapatkan tanggapan baru, dan keinginan untuk dikenal. ${ }^{7}$ Berdasarkan pada kenyataan dan gabungan dari empat keinginan tersebut, maka sejak dilahirkan manusia hidup dalam ketergantungan. ${ }^{8}$ Anak mengenal Tuhan pertama kali melalui bahasa, dari kata-kata orang yang ada dalam lingkungannya, yang ada awalnya diterima secara acuh. Terdapat beberapa teori yang menguatkan tentang hal ini.

1. Teori Rasa Ketergantungan (Sense of Dependent). Teori ini dikemukakan oleh Thomas melalui teori Four Wishes-nya. Menurut Thomas, manusia dilahirkan ke dunia ini memiliki empat keinginan yaitu: keinginan untuk perlindungan, keinginan akan pengalaman baru, keinginan untuk mendapat tanggapan, dan keinginan untuk dikenal.

2. Teori Instink Keagamaan. Hal ini dikemukakan oleh Woodworth bayi yang dilahirkan sudah memiliki beberapa instink, di antaranya instink keagamaan. Belum tampaknya tindak keagamaan pada diri anak karena fungsi kejiwaan yang menopang kematangan belum berfungsi sempurna. $^{9}$

\section{Ciri-Ciri Keagamaan Pada Anak-Anak}

Dasar nilai-nilai agama ditanamkan pada anak-anak pada masa sekolah dengan tahapan sesuai dengan usia dan untuk menerima kenyataan akan hal-hal yang tidak

${ }^{7}$ Sururin, Ilmu Jiwa Agama, (Jakarta: PT Raja Grapindo Persada:, 2004), hal, 48

${ }_{9}^{8}$ Sururin, Ilmu Jiwa Agama, hlm. 48.

9 Bambang Samsul Arifin, Psikologi Agama, (CV.PustakaSetia: Bandung, 2008), hlm. 49. 


\begin{tabular}{|l|l|r|}
\hline A1 Fitrah & Memahami Perkembangan Psikologi \\
\hline Journal Of Early Childhood Islamic Education & Keagamaan Anak Usia Dini \\
ISSN : 2599-2287 E-ISSN : 2622-335X & Fatrica Syafri \\
\hline
\end{tabular}

selamanya rasional. Ajaran agama dengan pola fisik maupun psikis anak-anak di usia sekolah dasar menunjukkan peran penting psikologi yang menjadikannya berkaitan erat dengan agama. Hal ini berkaitan dengan perkembangan intelektualitasnya yang semakin berkembang. ${ }^{10}$

Memahami konsep keagamaan pada anak berarti memahami sifat agama pada anak-anak. Sesuai dengan ciri yang mereka miliki, maka sifat keagamaan pada anak-anak tumbuh mengikuti pola "ideas concept on authority" idea keagamaan pada anak hampir sepenuhnya authoritarius maksudnya konsep keagamaan pada diri mereka dipengaruhi oleh unsur dari luar diri mereka. Mereka telah melihat dan mengikuti apa-apa yang dikerjakan dan diajarkan orang dewasa dan orang tua mereka tentang sesuatu hingga masalah agama. ${ }^{11}$

Dengan demikian ketaatan kepada ajaran agama merupakan kebiasaan yang menjadi milik anak yang mereka pelajari dan para orang tua maupun guru mereka. Berdasarkan hal tersebut maka bentuk dan sifat agama pada diri anak dapat dibagi atas :

1. Orientasi Egosentris (Egocentric Oriented)

Ciri keagamaan masa anak-anak yang pertama yang paling jelas adalah orientasi egosentris. Anak memiliki kesadaran akan diri sendiri sejak pada tahun pertama dalam pertumbuhannya dan

${ }^{10}$ Maramis, Ilmu Kedoteran Jiwa, (Jakarta :

Airlangga University Press, 1980), hlm. 22.

${ }^{11}$ Rama Yulis, Psikologi Agama, (Jakarta: Radar Jaya, 2011), hlm. 56. akan berkembang sejalan dengan pertambahan pengalamanya. Doa masa anak-anak dilandasi oleh orintasi egosentris.

a. Tingkat pertama, umur 5-7 tahun, anak secara sadar menghubungkan doa dengan tuhan atau formula doa tertentu yang diajarkan orang kepada mereka. Tetapi pengalaman doa itu tidak jelas dan tidak terperinci.

b. Tingkat kedua, umur 7-9 tahun, doa secara khusus dihubungkan dengan kegiatan atau gerak-gerik tertentu tetapi tetap kongkirit dan amat pribadi.

c. Tingkat ketiga, umur 9-12 tahun, ide tentang doa sebagai komunikasi antara anak dengan Tuhan mulai tampak.

Baru pada tahap tingkat ketiga itu isi doa beralih dan kenginan egosendtris (mendapatkan gula-gua, maianan, boneka, dan sebagainya) ke masalah yang tertuju pada orang lain dan bersifat etis (cinta sesama, perdamaian, tolong menolong). Ide anak-anak tentang tuhan pada awalnya, dibentuk dalam gambaran orang tua dalam kerangka kebutuhan anak-anak untuk menghadapi lingkungan hidupnya. Konsep dan ide pada masa ini belum berpikirkan dengan masak-masak tetapi lebih merupakan peniruan. $^{12}$

2. Ciri kedua keagamaan anak-anak

Ciri ini menjelaskan bahwa katakata dan gambaran-gambaran keagamaan diterjemahkan ke dalam pengalaman-

\footnotetext{
${ }^{12}$ Rama Yulis, Psikologi Agama, hlm. 57.
} 


\begin{tabular}{|l|l|r|}
\hline & Al Fitrah & Memahami Perkembangan Psikologi \\
Journal Of Early Childhood Islamic Education & Keagamaan Anak Usia Dini \\
ISSN : 2599-2287 E-ISSN : 2622-335X & Fatrica Syafri \\
\hline & Vol.2 No.1 Juli 2018 & \\
\hline
\end{tabular}

pengalaman yang sudah dijalani dan biasanya bentuk orang-orang yang sudah dikenal. Kekonkritan anak cenderung menjadi antropomorfis dalam penggambaran mereka tentang Tuhan. Tuhan dipikirkan dan digambarkan sebagai atau kakek. Jadi memiliki mata untuk melihat, tangan untuk memegang, dan lidah lidah untuk berbicara.

Menurut Praff, padangan anak tentang Tuhan itu mempunyai wajah seperti manusia, telinganya lebar dan besar. ${ }^{13}$

3. Eksperimentasi, inisiatif, spontanitas (experimentation, intiative, spontaneity)

Ciri ketiga, agama masa anak-anak itu tumbuh dan eksperimentasi dengan individualitas, inisiatif, dan spontanitas. Bersamaan dengan dunia anak yang cepat meluas melampai lingkaran keluarga, unsur-unsur baru yang cepat meluas melampai lingkaran keluarga, unsur-unsur baru berkenaan dengan maslah perpisahan mulai muncul. Umur 4, 5, 6 tahun meruapakan tahun kritis di mana anak mulai berani pergi keluar, mengambil inisiatif.

4. Kurang mendalam/tanpa kritik (Unreflective)

Ciri kurang mendalam atau kurang kritis. Artinya bahwa pemahaman anakanak terhadap ajaran agama dapat saja mereka terima tanpa kritik. Dalam penelitian Machion tentang sejumlah konsep ke-tuhanan pada diri anak 73\% mereka menganggap Tuhan itu bersifat seperti manusia. Selanjutnya dalam suatu sekolah ada yang mengatakan bahwa Sabta Klaus memotong jenggotnya untuk membuat bantal. Dengan demkian anggapan mereka terhadap ajaran agama dapat saja mereka terima dengan tanpa kritik. Penelitian proff mengemukakan salah satu contoh tentang hal itu :

Suatu peristiwa seorang anak mendapat keterangan dari ayahnya bahwa tuhan selalu mengabulkan permitaan hambanya. Kebetulan seorang anak berjalan di depan sebiah toka mainan sang anak tertarik dengan sebuah tapo berbentuk kerucut, sekembalinya ia ke rumah langsung berdoa kepada Tuhan untuk apa yang diingininya itu karena hal itu diketahui oleh ibunya. Maka ia tergiur. Ibunya berkata bahawa dalam berdoa tak boleh seseorang memaksakan Tuhan untuk mengabulakn barang yang diingininya itu. Mendengar hal tersebut anak tadi langsung mengemukakan pertanyaan "mengapa?"

Contoh di atas menunjukan, bahwa anak itu sudah menunjukan pemikiran yang kritis, walaupun bersefiata sederhana, menurut penelitian pikiran kritis bari timbul pada usia 12 tahun sejalan dengan pertumbuhan moral. Di usia tersebut, bahkan anak kurang cerdaspun menunjukan pemikirian yang korektif. Di sini terlihat bahwa anak meragukan

\footnotetext{
${ }^{13}$ Rama Yulis, Psikologi Agama, hlm. 58.
} 


\begin{tabular}{|l||l||r|}
\hline A1 Fitrah & Memahami Perkembangan Psikologi \\
\hline Journal Of Early Childhood Islamic Education & Keagamaan Anak Usia Dini \\
ISSN $:$ 2599-2287 E-ISSN : 2622-335X & Fatrica Syafri \\
\hline
\end{tabular}

kebenaran ajaran agama itu secara konkrit saja. $^{14}$

5. Ucapan dan praktik (verbalis dan ritualis)

Ciri kelima agama anak, berupa ucapan dan praktik. Dari pernyataan yang kita alami ternyata kehidupan agama pada anak-anak sebagian besar tumbuh mulamula dalam bentuk verbal (ucapan). Mereka menghafal secara verbal kalimatkalimat keagamaan dan selain itu amaliah yang mereka laksanakan berdasarkan pengalaman mereka menurut tuntunan yang diajarkan kepada mereka. ${ }^{15}$

6. Suka meniru (imitatif)

Ciri keenam agama anak adalah suka meniru. Berdoa danshilat misalnya mereka laksanakan karena hasil melihat perbuatan di lingkungannya, baik burupa pembiasaan ataupun pengajarkan yang intensif. Sifat peniru ini merupakan modal yang positif dalam pendidikan keagamaan pada anak. Menurut penelitian Gilsephy dan young terhadap sejumlah mahasiswa di salah satu perguruan tinggi Solo yang tidak memepunyai latar pendidikan dalam keluarga menunjukkan, bahwa anak yang tidak akan dapat diharapkan menjadi pemilik kematangan agama yang kekal. ${ }^{16}$

7. Rasa heran/kagum (Numinous)

Ciri ketujuh agama anak adalah rasa heran. Rasa rehan dan kagum merupakan tanda dan sifat keagamaan yang terakhir pada anak. Meraka hanya kagum terhadap

${ }^{14}$ Rama Yulis, Psikologi Agama, hlm. 59.

${ }^{15}$ Rama Yulis, Psikologi Agama, hlm. 60.

${ }^{16}$ Rama Yulis, Psikologi Agama, hlm. 61. keindahan lahiriah saja. Hal ini merupakan langkah pertama dari pernyataan kebutuhan anak dan akan dorongan untuk mengenal (new experience).

Menurut Rudolf Otto, kekagunaan tersebut berasal dari "The Wolly Othrs (yang sama sekali lain dari yang lain)". Dalam ajaran islam rasa kagum itu timbul karena manusia mengenal, memahami, dan menghayati sifat-sifat Tuhan yang Maha Baik dan Maha Sempurna, seperti yang terhimpunan dalam al-asma al-husna (nama-nama Tuhan yang baik) yang berjumlah 99 nama sifat).

Uraian di atas mengisyaratkan betapa pentingnya memberi keluasan kepada anak untuk bebas dalam emosi dan fantasinya tanpa ancaman dan teguran. ${ }^{17}$

Fase Perkembangan Agama pada AnakAnak

Perkembangan keberagamaan individu dalam usia 3-12 tahun. ${ }^{18}$ Menurut penelitian Ernes Hermar perkembangan beragama anak-anak melalui beberapa fase yaitu :

1. The Fairy Tale Stage (Tingkat Dongeng). Tingkatan ini dimulai pada anak yang berusia 3 tahun hingga 6 tahun. Pada tingkat ini konsep mengenai Tuhan lebih banyak dipengaruhi oleh fantasi dan emosi. Dalam tingkat perkembangan ini seakan-akan itu mehayati konsep ke-Tuhanan itu kurang masuk akal, sesuai dengan tingkat
${ }^{17}$ Rama Yulis, Psikologi Agama, hlm. 62.

18 Bambang Samsul Arifin, Psikologi 


\begin{tabular}{|l|l||r|}
\hline & Al Fitrah & \\
Journal Of Early Childhood Islamic Education & Memahami Perkembangan Psikologi \\
ISSN : 2599-2287 E-ISSN : 2622-335X & Keagamaan Anak Usia Dini \\
& Fol.2 No.1 Juli 2018 & Fatrica Syafri \\
\hline
\end{tabular}

perkembangan intelektualnya. Kehidupan masa ini masih banyak dipengaruhi kehidupan fantasi hingga dalam menggapai agama-pun anak masih menggunakan konsep fantastik yang diliputi oleh dongengdongeng yang kurang masuk akal.

2. The Raelistic Stage (Tingkat Kenyataan).Tingkat ini dimulai sejak anak masuk Sekolah dasar hingga sampai ke usai (masa usia) adolosense. Pada masa ini ide ke tuhanan anak sudah mencerminkan konsepkonsep yang berdasarkan kepala kenyataan (realis). Konsep ini timbul melalui lembagalembaga keagamaan dan pengajaran agama dan orang dewasa lainnya. Pada sama ini ide keagamaan pada anak didasarkan atas emosional, maka pada masa ini mereka telah melahirkan konsep tuhan yang formalis. Berdasarkan halitu maka pada masa ini anak-anak tertarik dan senang pada lembaga keagamaan yang mereka lihat dikerjakan oleh orang dewasa dalam lingkungan mereka. Segala bentuk tindak (amal) keagamaan mereka ikuti dan manusia tertarik untuk mempelajarinya.

3. The Individual Stage (Tingkat Individu). Pada tingkat ini anak telah memiliki kepekaan yang paling tinggi sejalan dengan perkembangan usia mereka. Konsep keagamaan yang individualistik ini terbagi atas tiga, yaitu; pertama, konsep ke-tuhanan yang Conversial dan formatif dengan dipengaruhi sebagian kecil fantasi. Hal tersebut disebabkan oleh pengaruh luar; kedua, konsep ke-tuhanan yang lebih murni dengan dinyatakan dengan pandangan yang bersifat persoanal (perorangan); ketiga, konsep ke-tuhanan yang bersifat humanistik. Agama telah menjadi ethos humanis dalam diri mereka dalam menghayati ajaran agama. Perubahan ini setiap tingkatan dipengaruhi oleh faktor intern yaitu perkembangan usia dan faktor ekstern pengaruh luar yang dialamainya. ${ }^{19}$

\section{Pendidikan Agama bagi Anak-Anak}

Meskipun para ahli masih belum memiliki kesempatan tentang asal-usul jiwa keagamaan pada manusia, pada umumnya mereka mengakui peran pendidikan dalam menanamkan rasa dan sikap keberagamaan pada manusia.

\section{Pendidikan Keluarga}

Anak-anak sejak usia masa bayi hingga usia sekolah memiliki lingkungan tunggal, yaitu keluarga. Gilbert Highest menyatakan bahwa kebiasaan yang dimiliki anak-anak sebagian besar terbentuk oleh pendidikan keluarga. Sejak bangun tidur hingga saat akan tidur kembali, anak-anak menerima pengaruh dan pendidikan dari lingkungan keluarga. Bayi yang baru lahir merupakan makhluk yang tak berdaya, namun ia dibekli oleh berbagai kemampuan yang bersifat bawaan, terlihat adanya dua aspek yang kontradiktif. Di satu pihak, bayi berada dalam kondisi tanpa daya, sedangkan di

19 Bambang Samsul Arifin, Psikologi 


\begin{tabular}{|l|l|r|}
\hline Al Fitrah & Memahami Perkembangan Psikologi \\
\hline Journal Of Early Childhood Islamic Education & Keagaman Anak Usia Dini \\
ISSN : 2599-2287 E-ISSN : 2622-335X & Fatrica Syafri \\
Vol.2 No.1 Juli 2018 & \\
\hline
\end{tabular}

pihak lain, bayi memiliki kemampuan untuk berkembang (eksploratif).

Keluarga menurut para pendidik merupakan lapangan pendidik yang pertama dan pendidiknya adalah kedua orang tua. Orang tua (bapak dan ibu) adalah kodrati. Mereka pendidik bagi anak-anaknya karena secara kodrati, ibu dan bapak diberikan anugerah oleh Tuhan Pencipta berupa naluri orang tua. Karena naluri ini, timbul rasa kasih sayang para orangtua kepada anak-anak mereka, hingga secara moral, keduanya merasa terkena beban tanggung jawab untuk memelihara, mengawasi, melindungi, dan membimbing mereka.

Menurut Rasulullah SAW, fungsi dan peran orangtua bahkan mampu membentuk arah keyakinnan anak-anak mereka. Menurut beliau, setiap bayi dilahirkan sudah memiliki potensi untuk beragama, namun bentuk keyakinan agama yang akan dianut anak sepenuhnya bergantung pada bimbingan, pemeliharaan, dan pengaruh kedua orang tua mereka.

\section{Pendidikan Kelembagaan Formal}

Pada masyarakat primitif, tak ada lembaga pendidik secara khusus. Anakanak umumnya dididik di lingkungan keluarga dan masyarakat lingkungannya. Pendidik secara kelembagaan memang belum diperlukan, karena variasi profesi dalam kehidupan belum ada. Pendidik agama di lembaga pendidik akan memberi pengaruh bagi pembentukkan jiwa keagamaan pada anak. Namun demikian, besar-kecilnya pengaruh tersebut sangat bergantung pada berbagai faktor yang dapat memotivasi anak untuk memahami nilai-nilai agama.

Kebiasaan adalah cara bertindak atau berbuat seragam. Dan pembentukan kebiasaan ini menurut Wetherington melalui 2 cara. Pertama, dengan cara pengulangan dan kedua, dengan disengajah dan direncanakan jika melalui pendidikan keluarga pembentukan jiwa keagamaan dapat dilakukan dengan menggunakan cara yang pertama, maka melalui kelembagaan pendidikan cara yang kedua, dampaknya akan lebih efektif. Fungsi sekolah dalam kaitannya dengan pembentukan jiwa keagamaan pada anak, antara lain sebagai penlanjut pendidikan agama pada lingkungan keluarga atau membentuk jiwa keagamaan pada diri anak yang tak diterima keluarga. ${ }^{20}$

\section{Pendidikan di Masyarakat}

Masyarakat merupakan lapangan pendidikan yang ketiga. Para pendidik umumnya sependapat bahwa lapangan pendidikan yang ikut mempengaruhi perkembangan anak didik adalah keluarga, lembaga pendidikan, dan lingkungan masyarakat. ${ }^{21}$ Dalam ruang lingkup yang luas, dapat diartikan bahwa pembentukan

20 Bambang Samsul Arifin, Psikologi Agama, hlm. 56. Agama, hlm, 58 


\begin{tabular}{|l|l||r|}
\hline & Al Fitrah & \\
Journal Of Early Childhood Islamic Education & Memahami Perkembangan Psikologi \\
ISSN : 2599-2287 E-ISSN : 2622-335X & Keagamaan Anak Usia Dini \\
& Fol.2 No.1 Juli 2018 & Fatrica Syafri \\
\hline
\end{tabular}

nilai-nilai kesopanan atau nilai-nilai yang berkaitan dengan aspek-aspek spiritual akan lebih efektif jika seseorang berada dalam lingkungan yang menjunjung tinggi nilai-nilai tersebut. $^{22}$

Disini terlihat hubungan antara lingkungan dan sifat masyarakat terhadap nilai-nilai agama. Lingkungan masyarakat santri barang kali akan lebih memberi pengaruh bagi pembentukan jiwa keagamaan dibandingkan dengan masyarakat lain yang memiliki ikatan yang longgar terhadap norma-norma keagamaan. Fungsi dan peranan masyarakat dalam pembentukan jiwa keagamaan akan sangat terkait dengan seberapa jauh masyarakat tersebut menjujung norma-norma keagamaan itu sendiri.

\section{Kesimpulan}

Perkembangan psikologi agama pada masa anak-anak yang pertama yang paling jelas adalah orientasi egosentris. Anak memiliki kesadaran akan diri sendiri sejak pada tahun pertama dalam pertumbuhannya dan akan berkembang sejalan dengan pertambahan pengalamanya. Baru pada tahap tingkat ketiga itu isi doa beralih dan kenginan egosendtris (mendapatkan gula-gua, maianan, boneka, dan sebagainya) ke masalah yang tertuju pada orang lain dan bersifat etis (cinta sesama, perdamaian, tolong menolong). Ide anak-anak tentang tuhan pada awalnya, dibentuk dalam gambaran orang Agama, hlm, 59 tua dalam kerangka kebutuhan anak-anak untuk menghadapi lingkungan hidupnya. Konsep dan ide pada masa ini belum berpikirkan dengan masak-masak tetapi lebih merupakan peniruan.

\section{Daftar Pustaka}

Arifin, Bambang Samsul. 2008. Psikologi Agama, Bandung: CV. Pustaka Setia.

Darajat, Zakiah. 1987. Ilmu Jiwa Agama, Jakarta: Bulan Bintang.

Jalaluddin, 2005. Psikologi Agama, Jakarta: Raja Grafindo Persada.

Jalaludin, 2004. Psikologi Agama, Jakarta: Rajawali Press.

Maramis, 1980. Ilmu Kedoteran Jiwa, Jakarta : Airlangga University Press.

Sururin, 2004. Ilmu Jiwa Agama, Jakarta: PT Raja Grapindo Persada.

Yulis, Rama. 2011. Psikologi Agama, Jakarta: Radar Jaya. 